\title{
THE EFFECT OF PRICE CONTROLS ON NON-PRICE COMPETITION
}

\author{
Wrot Alderson*
}

It has been said that the National Recovery Administration operated under a law which gave it legislative, executive, and judicial functions. But in retrospect it seems to have scarcely passed beyond the legislative phase in most of the matters which came under its jurisdiction. The essential part of its record for the economist is the record of the attempts to formulate policy in connection with the code-making process. The NRA, which might have assumed historic importance as an effort to operate under a new national economic policy, in practical effect resolved itself into a great national forum for the discussion of the elements of such a policy.

Questions of price control brought many divergent viewpoints into the national forum. Economists were in general opposed to such measures. Business men were much more divided in their opinions. But ampng these who favored some form of price control there were isrge firms and small firms, advertisers and non-advertiser, profitable and unprofitable concerns, manufacturers, wholesalers, asd rctailers. Is, short it could not be sa: that business men of this persuasion conformed to any particular type.

Arguments offered in favor of price control measures were of similar scope and variety. Very frequently their logic rested more on social grounds than on economic. An argument to which a number of economists listened with some sympathy was the plea for the preservation of the small enterprise as a means of giving fuller opportunities to individual initiative. An attempt was sometimes made to give this view a more acceptable economic flavor by insisting on the essential nature of the services performed by some of the firms which were on the verge of business failure. If these firms were not permitted to survive, it was argued, great social costs might be incurred in replacing them.

Similarly in the raw materials industries, such as coal and petroleum, the demand for price control was frequently linked with the need for conserving natural resources. Both types of arguments stressed structural features of economic life. Thus they created resistance and uneasiness in the minds of economists who preferred to

- Division of Commercial Research, Advertising Department, The Curtis Publishing Company, Philadelphia, Pa. Formerly economist on the staff of the National Recovery Administration. Contributor to periodicals of articles on problems in the field of marketing. 
teşt all control measures by the principle of competitive equilibrium. For them a measure was a bad measure if it seemed to create inelasticity by restricting competition. In recognizing the plea for the small enterprise or for the conservation of natural resources they felt that they were practical men, making concessions which could not be defended on wholly economic grounds.

Two approaches might have been taken in examining price control measures with relation to the maintenance of competition. The first, an attempt to show that the proposed form of control did not actually interfere with price flexibility, was explored at some length in a number of code discussions. Particularly with regard to arrangements allowing for minimum mark-ups to cover such functions as wholesaling and retailing and provisions designed to eliminate price discrimination, it was argued that the basic price level would still move up and down as freely as before. Such pleas were often presented on behalf of business groups by recognized economists, and sometimes admitted for code-making purposes by equally eminent economists engaged in advising the administration. Statistical price studies made subsequently at several universities have contributed something to the substantiation of this view.

But the other approach to a consideration of the effect of price control measures received no clear statement during the NRA period. That approach is to analyze the effect of price control on non-price forms of competition. Business men were struggling for an enunciation of such a viewpoint in their discussions of destructive price-cutting. The term "destructive price-cutting" was never given a clear-cut definition either by business men or administrative officials. But if non-price competition is given a place of equal importance with price competition, destructive price-cutting may be defined as that which destroys or seriously restricts non-price forms of competition.

The four major factors in non-price competition are held to be:

(a) Improvement in quality and service.

(b) Differentiation of product.

(c) Consumer advertising.

(d) Trade promotion.

Of these four the first is most basic. It is practically always present as an element in competition parallel to price competition, particularly in fabricated products. One recent writer ${ }^{1}$ states the view that the pressure of competition upward on quality is equally significant with the pressure of competition downward upon price. To some economists the emphasis upon competition in quality lies in the direction of semimonopoly and is likely to interfere with the attainment of competitive equilibrium. ${ }^{1}$ To the present writer it seems doubtful whether under our present form of industrial organization a true competitive equilibrium can be attained at all unless quality competition and price competition are equally vigorous. The full employment of

${ }^{1}$ Montgomery, The Consumer Looks at Distribution (Jan. 1937) J. OF MARketing. 
productive resources depends on the quality of the product turned out as well as upon the number of units produced. Full employment of resources does not occur until an industry is making the best quality of product that the market will absorb in the greatest number that the market will absorb. In theory, at least, there should be a price for each type of product which will bring about this balance between quality and number of units.

Further significance can then be offered for the term "destructive price cutting" which is so frequently heard in trade circles. It would mean the establishment of prices so low as to discourage the full employment of the industry's resources by necessitating cuts in the quality of the product offered. There might be some instances in which a definitely fixed price would be justifiable in these terms. In other words there might be products on which the definite fixing of the price would cause competition in quality to raise the actual value of the product up to a point that would justify that price. Such an argument would of course have to contemplate a degree of economic wisdom on the part of the agency fixing the price which is not always possessed either by public price-fixing bodies or by individual concerns in setting a price on their products.

But purely for purposes of analysis it may be worthwhile to assume for a moment that such a price has been fixed on a given product and to consider the various competitive devices which would tend to raise the marginal costs of the product to the level of the price so fixed. Improving the quality of the product has already been mentioned, but let us suppose that possible improvements in the product itself had been exhausted long before the level of the fixed price had been reached.

The next factor which would probably come into play would be the offering of various services accompanying the product. This might take the form of installation service or guarantees of quality in the case of durable products, or palatial retail establishments and liberal credit and delivery policies in the case of consumer goods. Both classes of service have in fact been widely offered. But let us further assume that all avenues had been exhausted for elaborating either the quality or the service features of the transaction.

The next type of non-price competition which is likely to be adopted lies in the direction of product differentiation. Product differentiation has been discussed by Chamberlin $^{2}$ and others as a semi-monopolistic attempt to escape from price competition. The alternative view is offered here that product differentiation may be looked upon as an attempt to extend quality competition. Suppose, for example, that the basic quality dimension of the product is durability. In a given case the possibility of rendering the product more durable may have been exhausted before costs have been raised to the fixed price of the product. Also it may be that, after that point has been reached, the customers for the product may be considered to be divided into groups according to their interest in other quality dimensions such as

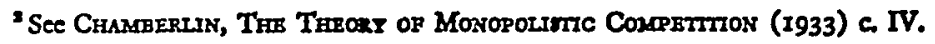


appearance and convenience in use. Additional increases in quality might then occur but with a different phase being stressed in each of the several groups. It might be assumed that the result of competition would then be to close the gap remaining between cost and the fixed price by making equivalent additions to value along different quality dimensions rather than making identical improvements along the same quality dimension.

Under this analysis product differentiation would not move away from competition but would be one means of maximizing the supply of equivalent utilities offered in the product at the fixed price. The final competitive means of raising cost to the fixed price would lie in increasing expenditures for sales promotion. Sales costs are the most elastic elements in costs. Since sales costs are subject to operating decisions in the most competitive of industries, economists have experienced difficulty in relating sales costs to the standard analysis of the competitive equilibrium. In relation to the hypothetical example in which the sales price is assumed to be fixed, the flexibility of sales costs is the final element necessary to the attainment of equilibrium in non-price competition. Such an increase in sales cost should not be considered as wholly lacking in social utility. Every improvement in quality and every product differentiation will require additional selling effort to acquaint the consumer with such improvements. The new aspect of quality will not prove wholly effective in use without consumer understanding of its advantages. On the other hand, it is difficult to increase sales costs beyond the minimum required by the routine movement of goods without something special of a quality nature to be sold.

It is probable then that neither of the two basic elements in non-price competition would ever be wholly lacking. That is to say that the increase in cost upward toward the fixed price would always combine the two elements of quality improvement and additional sales costs in some proportion. Whether the actual increase in the utility offered to the consumer would be in proportion to the increase in the price will not be considered in detail here.

There would always be additional factors beyond those which have been suggested bearing on the question of how much real utility would be given at the fixed price. In the first place the question is scarcely capable of solution in exact mathematical terms when several dissimilar quality dimensions are involved in the same cost-raising process. Another factor is the effect on the price of labor and raw materials entering into the product which would result from quality competition and tend to diminish the value which the consumer would receive at the fixed price. It would, however, have the social value of increasing the disbursements of purchasing power to labor and raw material suppliers. Counterbalancing this tendency would be the elimination of marginal firms by quality competition resulting in a higher average efficiency among the remaining suppliers, and presumably a greater ablity to provide quality in the product.

The increase in the cost of selling has been treated so far as a single element. It 
may now be considered in terms of its two major components, namely the consumer education usually carried on by means of advertising and the trade cooperation which the manufacturer seeks to obtain by means of the margins which he allows to retailers and wholesalers. The manufacturer's use of these two forms of sales effort will differ in any number of respects in accordance, with the types of price control which are in effect.

The remainder of the discussion can best be developed in terms of the probable effect on these two elements of sales costs of the various price control situations which may arise under recent legislation, namely the Robinson-Patman Act and the state "fair trade" laws. Three control situations will be considered for the purpose of analysis although there are many other variations which may arise in practice. These three situations may be designated as Situations $A, B$, and $C$, as follows:

Situation A-Strict enforcement of the Robinson-Patman Act but general tendency of manufacturers not to issue contracts under the "fair trade" laws.

Situation $B-$ General use of resale price contracts establishing margins satisfactory to the retailer with the Robinson-Patman Act permitted to become a dead letter.

Situation C-Full use of both forms of control.

In the first instance where prices were controlled at the top but not at the bottom the tendency would be both to equalize competition among retailers and at the same time to intensify it. Strict enforcement of the Robinson-Patman Act would mean the elimination of any discriminatory advantage in buying which may have been available to the larger retail organizations. Such concerns, in order to hold their position in the market, would use all of the competitive devices available to them in attempting to maintain retail volume. Price competition would continue in undiminished force but quality and service features would also receive increasing emphasis. The small retailer would be enabled to meet the price competition of the larger organization and the larger organization would be obliged to meet the quality and service competition of the independent retailer.

Under Situation B, with prices controlled at the bottom but open at the top, price. competition between retailers would be restricted without an equalization of competitive advantages on the buying side. The probable result would be a marked increase in quality and service elements in the competitive efforts of the large retail organizations. But it is likely that only a minor part of the new service elements to be introduced would take the form of service to the consumer. The power to demand price concessions from the manufacturer has been associated in the past with the capacity to offer special services to the manufacturer. In other words, the retailer normally offers to take over certain sales and promotion functions, which the manufacturer might perform in other cases, in return for the special price concessions. Such concessions would no doubt tend to be increased, with an increasing portion of the manufacturer's budget for advertising and promotion expended in the form of concessions to retail organizations who undertook to promote his product for him. 
Under Situation $C$, with control of price both at the top and the bottom, the tendency would be to equalize competition among retailers and at the same time center the resulting competition upon quality and service features. While price appeal might remain as an element of retail merchandising in such aspects as odd cent pricing and occasional special sales, the ability of one section of the retail trade to profit at the expense of another by means of loss-leader selling: would practically disappear. The large retail organization would lose both the special price concessions which make it easier to create price reductions and the privilege of accepting margins lower than the minimums satisfactory to other retailers. Expensive store atmosphere and elaborate consumer service would no doubt be expanded presently by the larger retail organizations.

In assaying the comparative effect of these three situations upon the manufacturer's use of consumer advertising, it is necessary to take account of two aspects of the manufacturer's advertising policy. The first aspect may be called the strategic aspect. This term is meant to characterize the considerations governing the manufacturer's choice between methods of sales promotion. The effect of a control situation on the strategic aspect of advertising policy would be to increase or decrease the manufacturer's desire to use advertising in contrast with other methods.

The second aspect of policy may be called the budgetary aspect. The effect of a control situation on the budgetary aspect is to increase or decrease the amount of funds which the manufacturer has available for use in such promotional efforts as advertising.

The probable effect of the three price control situations on advertising expenditures may now be described in terms of these two phases of advertising policy.

Situation A (prices controlled at the top and open at the bottom) would be favorable to an increase in advertising expenditures for both strategic and budgetary reasons. On the strategic side the manufacturer would now lack the special efforts which large retailers had made in return for price concessions and at the same time would need to overcome any trade resistance arising from the unrestricted price cutting to which his product might be subjected. On the budgetary side large amounts of money would be made available for advertising use by wiping out the special arrangements that may previously have existed with large retailers. In this connection it must be remembered that the Robinson-Patman Act proceeds in two major directions. The first is the elimination of discrimination by requiring that quantity discount schedules be related to relative costs of serving different customers. The second is by directly limiting the use of such promotional devices as advertising allowances and payments to retailers for demonstrators.

While Situation $A$ is the most favorable of the three to increased advertising expenditures, Situation B (prices controlled at the bottom and open at the top) would be the least favorable. In this case both strategic and budgetary considerations would weigh against the use of advertising. This situation would give the large 
retailer a preponderant place in the control of distribution so that the manufacturer's efforts would be directed even more than before toward cultivating the good-will of such leading retail organizations. The budget available for advertising would be decreased by diversion both to the protected margins granted to all retailers and the promotional allowances granted to the larger organizations.

The effect of Situation C (prices controlled at both top and bottom) would be moderately favorable to the increase of advertising expenditures, particularly in the more selective advertising media. Strategic considerations would be favorable to advertising and budgetary considerations moderately unfavorable. With the equalization of competition in the retail field and the better retail relations resulting from protected margins, a greater number of manufacturers than ever before would find the situation favorable to putting most of their sales promotion effort into advertising.

On the other hand, the granting of protected margins to the retailer would tend to decrease the advertising budget of some of the manufacturers who had previously been advertising. Such decreases would probably 'more than offset the savings which they effected by withdrawing promotional allowances to retail organizations. Manufacturers would then be confronted with the need for getting increased advertising effectiveness out of their advertising expenditure because of some decrease in price flexibility resulting from protected margins for the retailer. Generally speaking they would have to obtain this increased advertising effectiveness on the same or somewhat decreased advertising budgets. The apparent result would be to cause manufacturers to examine the character of their advertising expenditures more closely than ever before and to make very rigorous selection of advertising media. More complete data would be demanded from all advertising media as to the character of the markets they reach and more detailed facts supporting their claims for advertising effectiveness. Thus the price control situation, while creating a more secure place for quality competition in the product itself, would at the same time intensify quality competition among the advertising media through which the product was to be merchandised.

Other types of legislation for the control of distribution are under consideration. Any type that will be introduced will change the control situation and call for a modification of the analysis of the results. One such possibility is further government control of quality in certain fields such as the proposed revision of the Food and Drugs Act. Various measures for the control of quality will react in various ways on both quality competition and price competition. Perhaps the one clear conclusion that may be drawn from this attempt to analyze the effect of price control on nonprice competition is the need for paying attention to the total situation. That is to say that it is not feasible to consider separately the possible effect of such measures as the Robinson-Patman Act or the state "fair trade" laws. The probable result must be considered in terms of the combination of control measures which are actually effective at a given time. 